\title{
Avascular necrosis of the bilateral femoral head with pregnancy: A case report
}

\author{
Hamilelik döneminde gelişen bilateral femur başı avasküler nekrozu: Olgu sunumu
}

Türkan TURGAY, Ali AYDENIZ² $^{2}$

\begin{abstract}
Summary
Osteonecrosis, also called avascular necrosis, of the femoral head is a pathologic process resulting from an inadequate blood supply. The death of cells in bone tissue can cause the collapse of the affected joint. It is a progressive disease primarily affecting adults in middle age and can lead to substantial loss of joint function. Osteonecrosis of the femoral head during or just after pregnancy is a rare clinical entity. Although many causes of femoral head osteonecrosis have been identified, little is known about pregnancy as an etiological factor. Presently described is the case of a 30-year-old female with bilateral osteonecrosis of the femoral head that developed during the peripartum period.
\end{abstract}

Keywords: Avascular necrosis; hip; pregnancy.

\section{Özet}

Femur başı osteonekrozu veya avasküler nekrozu, yetersiz kan beslenmesinden dolayı kemik dokusunda hücrelerin ölümüne ve eklemin çökmesine neden olan patolojik bir süreçtir. Avasküler nekroz, esas olarak orta yaş yetişkinleri etkileyen ve eklem fonksiyonunda ciddi kayıplara yol açan ilerleyici bir hastalıktır. Gebelik sırasında veya hamilelikten hemen sonra femur başının osteonekrozu nadir görülen bir klinik durumdur. Femur başı steonekrozun birçok sebebinin iyi bilinmesine rağmen, etiyolojik bir faktör olan gebelik için çok az şey bilinmektedir. Peripartum dönemde gelişen femur başı bilateral avasküler nekrozu olan 30 yaşında bir kadın hastanın olgusunu sunmaktayız.

Anahtar sözcükler: Avasküler nekroz; kalça; gebelik.

\section{Introduction}

Osteonecrosis refers to a clinical syndrome in which regional death of the celuler elements of bone typically in a subchondral location leads to trabecular and subchondral collapse with consequent pain, impairment and long term joint damage. ${ }^{[1]}$ It seems to be most common in men between the ages of 30 and 50 years. ${ }^{[2]}$

Although the pathophysiological mechanisms of atraumatic femoral head necrosis have not been conclusively clarified, femoral head ischemia is independent of the etiology. Long-term corticosteroid treatment, excessive alcohol consumption, smoking, hemoglobinopathy, sickle-cell anemia, coagulopathy, myeloproliferative disease, gaucher's disease, leukemia, pregnancy are the risk factors for atraumatic femoral head necrosis. ${ }^{[3]}$

However, osteonecrosis of the femoral head during or just after pregnancy is a rare clinical problem which was first described by Pfeifer in 1957. ${ }^{[4]}$

The purpose of this case to highlight the importance of bilateral osteonecrosis as a cause of groin pain in a pregnant women.

\section{Case Report}

A healthy 30-year-old woman presented with right leg and groin pain for 3 weeks before giving birth to a $4.3 \mathrm{~kg}$ male baby by caesarian section (Gravida 2, Para 2, Abortion 0) at 40 weeks' gestation. Her weight

\footnotetext{
'Department of Physiotheraphy and Rehabilitation, Sanko University School of Health Sciencies, Gaziantep, Turkey 2Department of Physical Medicine and Rehabilitation, Gaziantep University Faculty of Medicine, Gaziantep, Turkey

Submitted: 26.05.2018 Accepted after revision: 12.11.2018 Available online date: 19.11.2018
}

Correspondence: Dr. Ali Aydeniz. Gaziantep Üniversitesi Tıp Fakültesi, Fiziksel Tıp ve Rehabilitasyon Anabilim Dalı, 27310 Gaziantep, Turkey. Phone: +90 - 342 - 3606060 e-mail: aliayden@gmail.com

(c) 2020 Turkish Society of Algology 


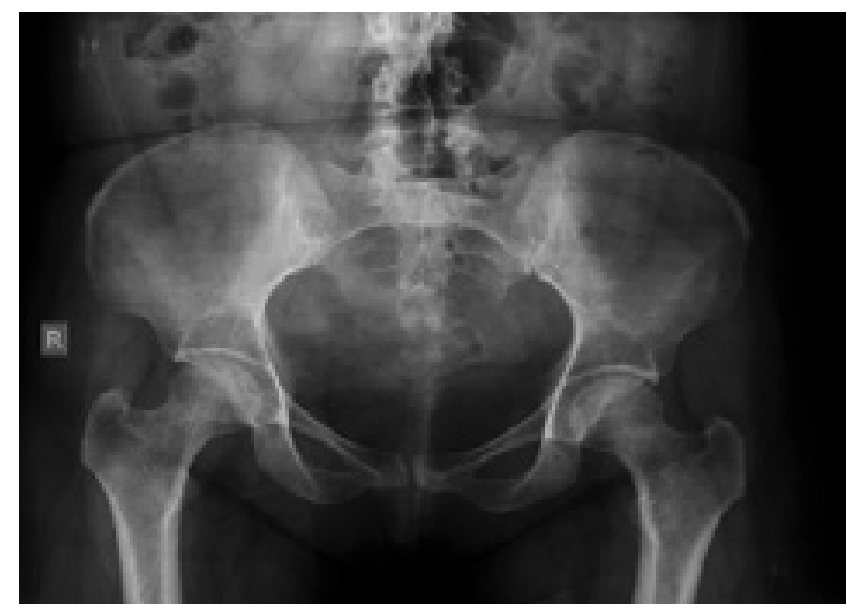

Figure 1. Anteroposterior radiographs of the pelvis; bilateral osteonecrosis of the femoral head with flattening of the surface and early sings of osteoarthritis.

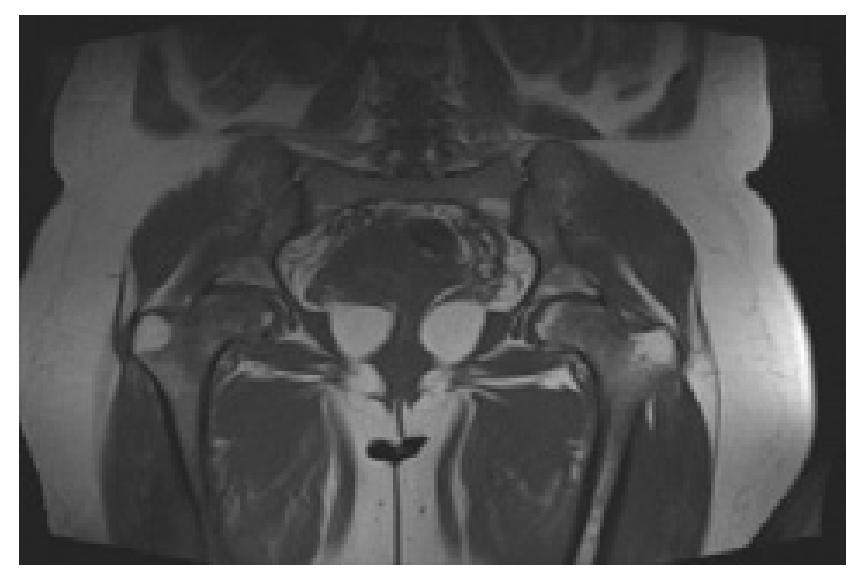

Figure 2. Coronal T1 -weighted magnetic resonance imaging of bilateral femoral heads.

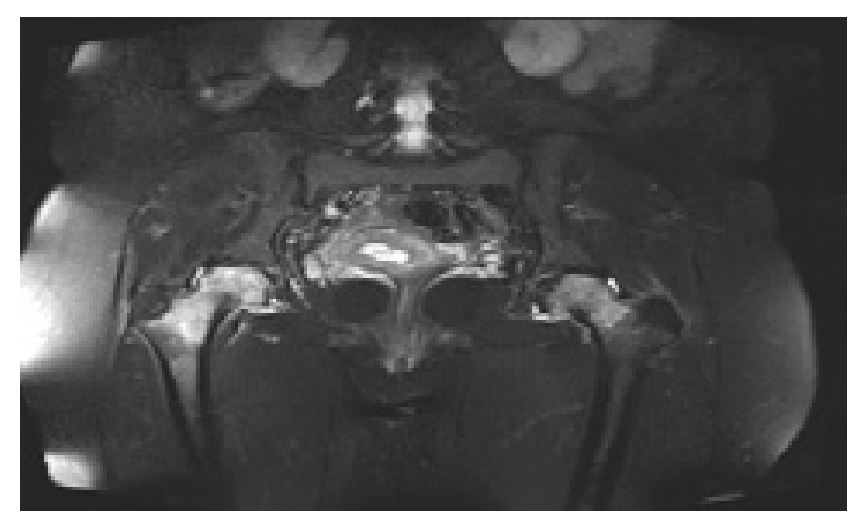

Figure 3. Coronal T2-weighted magnetic resonance imaging of bilateral femoral heads.

gain during this pregnancy was $20 \mathrm{~kg}$ (pregnant body weight $80 \mathrm{~kg}$; body height $150 \mathrm{~cm}$; BMI (Body Mass Index) $35.6 \mathrm{~kg} / \mathrm{m}^{2}$ ). Her pain and gait difficulty aggravated immediately following the delivery and made it difficult for the patient to walk. The patient had no history of contraceptive drug use, autoimmune diseases, trauma, coagulation disorders, alcohol drinking, chronic corticosteroid useage, smok-

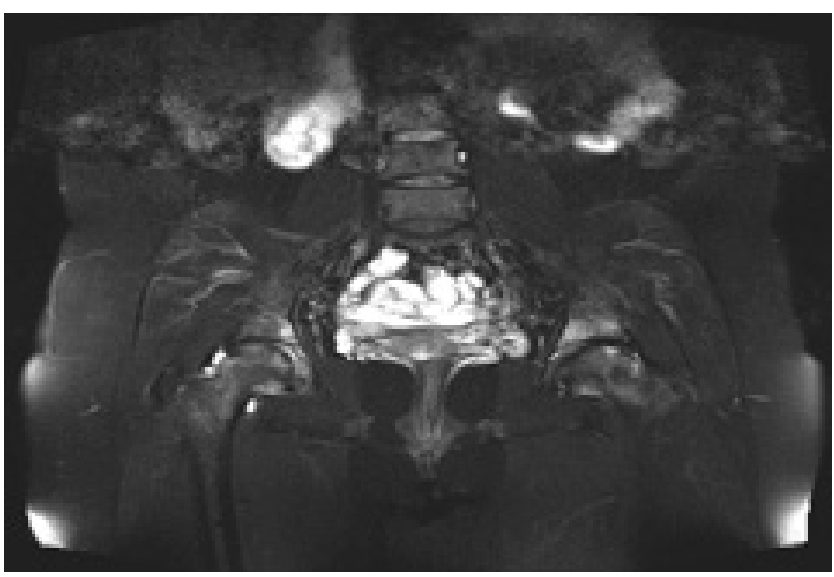

Figure 4. Coronal T2-weighted magnetic resonance imaging of bilateral femoral heads on follow-up MRIs after conservative treatments.

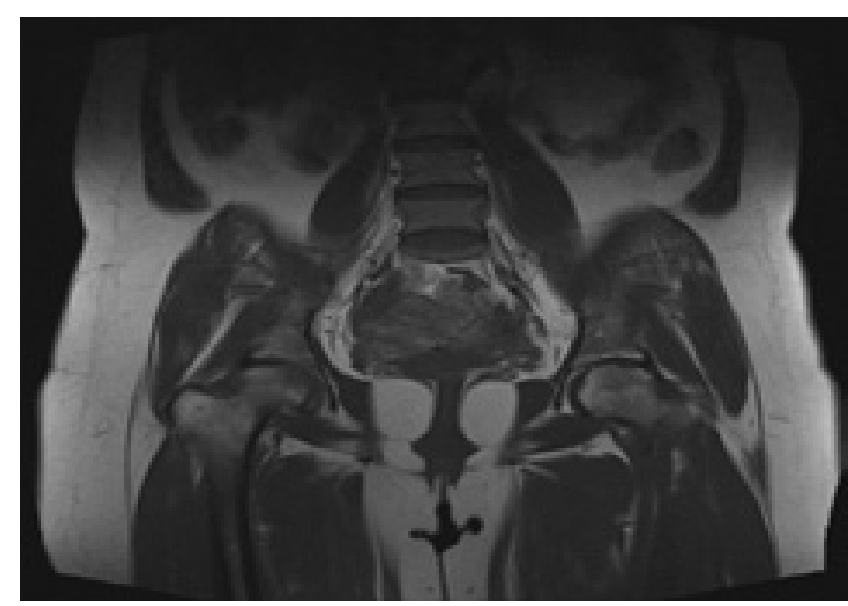

Figure 5. Coronal T1-weighted magnetic resonance imaging of bilateral femoral heads on follow-up MRIs after conservative treatments.

ing or ovarian hyperstimulation syndrome. Results of laboratory tests were as follows: ESR: $25 \mathrm{~mm} /$ first hour, WBC: $10.320 / \mathrm{mm}^{3}$ and CRP: $10 \mathrm{mg} / \mathrm{l}$. Rheumatoid factor was negative. Coagulation parameters (antiphospholipid and anticardiolipin antibodies and protein S) were negative, parathyroid hormone was normal range and also normal lipidic analysis except for mild hypertriglyceridemia $(216 \mathrm{mg} / \mathrm{dl})$. Her past medical history was only significant for right venous stasis evaluated femoral head blood flow using doppler ultrasonography of bilaterally lower extremity in last trimester. Therefore she was taking enoksaparin sodium 6000 ANTI-XA/0.6 ml sc during 3 weeks before delivery. On physical examination, range of motion was found to be limited with a positive Patrick's (flexion abduction external rotation) test in both side and movement was painful. Pain was measured using a $100 \mathrm{~mm}$ visual analogue scale (VAS). VAS score was $90 \mathrm{~mm}$ in our patient at baseline. However, she experienced deep 
anterior pain in her right hip with terminal flexion. The lower extremity neurologic examination was normal. She had a positive Trendelenburg gait on the left side. Plain anteroposterior radiographs of the hip was nonspecific.

The first MRI of the left hip showed suspicious subchondral fractures in osteonecrosis of the femoral head without collapse and diffuse edema involving the femoral head, neck on T1- and T2-weighted images.

MRI follow-up after conservative treatment was performed as well as regression of the edema extending to the femoral head and neck, progression of the acetabular subchondral edema and focal of areas osteonecrosis in the both femoral heads without collapse.

Results of examinations and magnetic resonance imaging were consistent with diagnosis of avascular osteonecrosis of the bilateral femoral head (Figs.)

The patient was offered avoiding vigouros exercise and a walker using was recommended for reducing weight bearing. Hyperbaric oxygen treatment was performed two days in a week and medical and physical therapy was started to relief the pain.

\section{Discussion}

Aseptic necrosis, known as avascular necrosis, ischemic necrosis, or osteonecrosis, is a pathological process caused by impaired blood supply to the affected bone and resulted in the death of osteocytes and bone marrow cells. ${ }^{[5]}$ Bilateral aseptic osteonecrosis of femoral head associated to pregnancy is very rare. ${ }^{[6,7]}$ The most complaint is mostly unilateral, gradually increasing pain in the groin and radiating to the knee and thigh exacerbated by activity and exercise.

Apart from traumatic forms, the etiology and the pathogenetic mechanism of osteonecrosis of the femoral head associated pregnancy are still controversial and probably multifactorial. Hormonal influences, increased coagulability, mechanical stress or overload by excessive labor and weight gain during the last trimester of pregnancy and impaired venous stasis are some speculative mechanisms that have been proposed. ${ }^{[8-10]}$ In our case there was right venous stasis evaluated femoral head blood flow using doppler ultrasonography of bilaterally lower extremity. Her BMI was $>30$ based on the mother's body mass index in last trimester and she delivered a baby boy weighing more than $4 \mathrm{~kg}$ at birth considered larger than average.

In literature many cases were mostly on the left side (excessive compression of the iliac vein on the left side due to the anatomy?), the causation hypothesis is logical and may confirm the theory of excessive compression ${ }^{[11,12]}$ of the iliac veins (and particularly on the left side) from the weight of the developing fetus.

Furthermore, many endocrine modifications occur during pregnancy such as parathyroid hyperplasia and the production of estrogen and progesterone by the placenta. ${ }^{[13]}$ The elevated non-protein bound cortisol and glucocorticoid activity of progesterone can be responsible. ${ }^{[9]}$ In our patient, the biochemical and coagulation parameters showed no abnormalities except for mild hypertrigliceridemia.

Conservative methods are usually started when there is no evidence of collapse such as restricted weight bearing, physical theraphy, medication, hyperbaric oxygen treatment, electrical stimulation, extracorporeal shock-wave treatment. ${ }^{[14]}$ Joint-preserving operations are performed principally in ARCO stage I and II femoral head necrosis, but can also be carried out in stage III disease, depending on the severity and site of necrosis. ${ }^{[15]}$ In our patient we performed hyperbaric oxygen treatment and physical therapy to maintain muscle strength and prevent contractures and she had remarkable pain relief and functional progress. After treatment patient's VAS score was $30 \mathrm{~mm}$ at 2-month follow-up visit. We defined the change in the VAS that the patient perceived as meaningful.

In conclusion in this case we reported bilateral osteonecrosis of femoral head that developed during the last trimester of pregnancy. Pregnancy-associated bilateral hip avascular necrosis is relatively uncommon and physicians schould be aware of this rare entity to establish the diagnosis and appropriate treatment protocol. 


\section{Informed Consent: Written informed consent was obtained from the patient for the publication of the case report and the accompanying images.}

\section{Conflict-of-interest issues regarding the author- ship or article: None declared.}

\section{Peer-rewiew: Externally peer-reviewed.}

\section{References}

1. Hochberg MC, Silman AJ, Smolen JS, Weinblatt ME, Weisman MH. Rheumatology, $6^{\text {th }}$ Edition. Elsevier 2015;184:1528-9.

2. Lieberman JR, Berry DJ, Montv MA, Aaron RK, Callaghan $J J$, Rayadhyaksha A, et al. Osteonecrosis of the hip: Management in the twenty-firstcentury. J Bone Joint Surg Am 2002;84(5):834-53. [CrossRef]

3. Aldridge JM ${ }^{\text {rd }}$, Urbaniak JR. Avascular necrosis of the femoral head: etiology, pathophysiology, classification, and current treatment guidelines. Am J Orthop (Belle Mead NJ) 2004;33(7):327-32.

4. Pfeifer W. A case of unusual form and origin of bilateral symmetrical osteonecrosis of the femoral \& humerus heads. Fortschr Geb Rontgenstr Nuklearmed 1957;86(3):346-9. [Article in German] [CrossRef]

5. Lin YC, Chen WS, Chang CC, Chen M, Yu CT. Aseptic necrosis of bilateral femoral heads after pregnancy. Taiwan J Obstet Gynecol 2011;50(1):111-3. [CrossRef]

6. Ugwonali OF, Sarkissian H, Nercessian OA. Bilateral osteo- necrosis of the femoral head associated with pregnancy: four new cases and a review of the literature. Orthopedics 2008;31(2):183. [CrossRef]

7. Vandenbussche E, Madhar M, Nich C, Zribi W, Abdallah T, Augereau B. Bilateral osteonecrosis of the femoral head after pregnancy. Arch Orthop Trauma Surg 2005;125(3):201-3.

8. Montella BJ, Nunley JA, Urbaniak JR. Osteonecrosis of the femoral head associated with pregnancy. A preliminary report. J Bone Joint Surg Am 1999;81(6):790-8. [CrossRef]

9. Gribble RK, Emanuel Berres L. Idiopathic osteonecrosis of the hip during pregnancy: outcome in a subsequent gestation. Obstet Gynecol 2001;98:911-3. [CrossRef]

10. Hasegawa Y, Iwase T, Iwasada S, Kitamura S, Iwata H. Osteonecrosis of the femoral head associated with pregnancy. Arch Orthop Trauma Surg 1999;119(1-2):112-4. [CrossRef]

11. Ginsberg JS, Brill-Edwards P, Bona R, Burrows R. Deep vein thrombosis (DVT) during pregnancy: leg and trimester of presentation. Thromb Haemost 1991;65:720.

12. Cockett FB, Thomas ML. The iliac compression syndrome. Br J Surg 1965;52(10):816-21. [CrossRef]

13. Lausten GS. Osteonecrosis of the femoral head during pregnancy. Arch Orthop Trauma Surg 1991;110:214-25. [CrossRef]

14. Lüring C, Beckmann J, Pennekamp PH, Linhardt O, Grifka $\mathrm{J}$, Tingart M. Conservative treatment of aseptic necrosis of the femoral head. Are there evidence-based therapy concepts? Orthopade 2007;36(5):441-2. [Article in German]

15. Im GI, Kim DY, Shin JH, Cho WH, Lee CJ. Degeneration of the acetabular cartilage in osteonecrosis of the femoral head: histopathologic examination of 15 hips. Acta Orthop Scand 2000;71(1):28-30. [CrossRef] 